\title{
Hepatic Infection
}

National Cancer Institute

\section{Source}

National Cancer Institute. Hepatic Infection. NCI Thesaurus. Code C78339.

An acute or chronic infectious process affecting the liver. 